\title{
Low-temperature Plasma Assisted Thermochemical Treatments of AISI 420 Steel: Comparative Study of Obtained Layers
}

\author{
Cristiano José Scheuer, ${ }^{a, b}$, Rodrigo Perito Cardoso ${ }^{a}$, Silvio Francisco Brunatto ${ }^{a *}$ \\ ${ }^{a}$ Tecnologia de Fabricação Assistida por Plasma e Metalurgia do Pó, Laboratório de Plasma e \\ Tecnologia em Pós - LTPP, Departamento de Engenaharia Mecânica, Universidade Federal do \\ Paraná-UFPR, Av. Cel. Francisco H. dos Santos, 210, \\ Jardim das Américas, CEP 81531-980, Curitiba, PR, Brazil \\ ${ }^{b}$ Colégio Técnico Industrial de Santa Maria, Universidade Federal de Santa Maria - UFSM, \\ Av. Roraima, 1000, Prédio 5, Camobi, CEP 97105-900, Santa Maria, RS, Brazil
}

Received: September 16, 2015; Revised: September 21, 2015

\begin{abstract}
Formation of metastable $\mathrm{C}-, \mathrm{N}-$, or even Formation of metastable $\mathrm{C}-, \mathrm{N}-$, or even $\mathrm{C} / \mathrm{N}-$ expanded phases can be observed for typical non-equilibrium conditions attained at the plasma assisted thermochemical treatments when temperatures relatively low are used. In present work, kinetics data are considered in a comparative study comprising low-temperature plasma assisted carburizing, nitriding and nitrocarburizing of AISI 420 martensitic stainless steel samples treated at 350, 400, and $450{ }^{\circ} \mathrm{C}$, aiming to put in evidence the main metallurgical differences of the obtained layers. Microstructural characterization and hardness measurement results for untreated and treated sample surfaces show significant difference for the carburized layer growth in relation to that verified for the nitrided and nitrocarburized layers. While the carburized layer is constituted of a thin outer layer and a deep diffusion layer, just the opposite was observed for the other two treatments, id est., formation of thicker outer layers and thinner diffusion layers. Finally, carbide-/nitride-precipitation-free layers were supposedly obtained for samples carburized, nitrided, and nitrocarburized at $350{ }^{\circ} \mathrm{C}$ temperature.
\end{abstract}

Keywords: low temperature plasma thermochemical treatments, carburizing, nitrocarburizing, nitriding, AISI 420 martensitic stainless steel

\section{Introduction}

Different techniques of surface engineering have been strongly applied aiming to improve the surface properties of engineering materials, thus enhancing the material/part life in operation for distinct applications. In this case, the main objective is to develop a wide range of functional properties that complement the substrate bulk characteristics, improving the material performance as a whole. Comprising a significant $R \& D$ field on the surface engineering, thermochemical treatments are thermally activated processes by which atoms from the treatment atmosphere (usually, N, C, or both) diffuse into the material, leading the surface microstructure and thus its properties to be modified. Nitriding, carburizing, and nitrocarburizing are typical examples of thermochemical treatments ${ }^{1}$, being usually carried out in solid, liquid or gaseous media, presenting one or more reactive chemical elements, in the case, $\mathrm{N}, \mathrm{C}$, and $\mathrm{N}+\mathrm{C}$, respectively. On the other hand, plasma assisted thermochemical techniques have experienced fast industrial acceptance between the 1970s and 1980s, making it vital to many of the largest world manufacturing industries ${ }^{2}$. The advantages over conventional thermochemical treatments (solid, liquid and gas media) include: shorter cycle times, greater energy efficiency, low gas consumption, lower environmental impact by the strongly reduced emission of pollutants or toxic wastes, the obtainment of finished surfaces, among others ${ }^{3-5}$.

*e-mail: brunatto@ufpr.br
The great potential of plasma assisted thermochemical techniques is due to the excellent surface properties obtained through their application in most of the engineering materials ${ }^{6}$. In the case of stainless steels, good combination between tribological properties and corrosion resistance can be obtained even for low temperatures or short treatment times $^{7-12}$. As known, when these treatments are performed at high temperatures (usually above $450{ }^{\circ} \mathrm{C}$ ), chromium nitride/carbide precipitation occurs, leading to a reduction of the material corrosion resistance ${ }^{13,14}$.

The very well established Fe-C, Fe-N, Fe-C-N equilibrium systems are important tools aiming to base carburizing, nitriding, and nitrocarburizing thermochemical treatments of iron alloys, respectively. But, for the purpose of stainless steels treatment, the presence of $\mathrm{Cr}$ in these alloys imposes important changes in related systems. This is especially true by exposing the stainless steel to temperatures relatively high (usually $>500{ }^{\circ} \mathrm{C}$ ), for which stable $\mathrm{Cr}$ carbides and nitrides tend to be formed, leading to the steel sensitization. Otherwise, formation of metastable phases like C-, N-, or even $\mathrm{C} / \mathrm{N}$-expanded phases can be observed for the typical non-equilibrium conditions observed at the plasma assisted thermochemical treatments, allied to the use of temperatures relatively low.

The research interest on low-temperature thermochemical treatments for stainless steels has been strongly increased 
from the 1980s after the nitrogen-expanded austenite phase $\left(\gamma_{\mathrm{N}}\right.$ or $S$-phase) was achieved ${ }^{6,7}$. As a main result of this goal, many plasma assisted treatments have been successfully tested and applied for stainless steels, making possible to achieve wear and corrosion resistance improvements for the treated materials ${ }^{6}$. In addition, as previously related by Scheuer et al. ${ }^{15}$ making reference to other authors, different plasma assisted techniques comprising DC plasma, RF plasma, plasma-based low-energy ion implantation, and plasma immersion ion implantation have been also tested for stainless steels. The great amount of works published on stainless steels pulsed DC plasma treatments confirms the technological potential of this technique. Considering the martensitic stainless steels, many works have been found reporting the use of low-temperature DC plasma assisted nitriding ${ }^{6,9,16-22}$, nitrocarburizing ${ }^{6,22-26}$, and carburizing ${ }^{6,15,27,28}$.

Regarding the improvement of the martensitic stainless steels surface properties by low-temperature plasma nitriding ${ }^{6}$, and ${ }^{16}$ reported that the corrosion resistance of the nitrided AISI 420 and AISI 410 steel samples can be increased in relation to the untreated material. In terms of fatigue behavior, $\mathrm{Xi}$ et al. ${ }^{18}$ noted that the fatigue failure limit was increased on the order of $25 \%$ for nitrided AISI 420 steel samples when compared to the untreated substrate. It was also found a decrease of the friction coefficient from 0.8 to 0.65 after plasma nitriding, suggesting wear behavior improvement of the treated material. Xi et al. ${ }^{18}$ also confirmed the results previously obtained by Corengia et al. ${ }^{17}$, who had described that nitrided AISI 410 steel samples exhibit a lower friction coefficient and a lower wear rate by comparing with untreated samples. Recently, cavitation resistance of AISI 410 steel after plasma nitriding treatment was studied $\mathrm{in}^{21}$, and significant results for cavitation-erosion behavior of low-temperature plasma nitrided CA-6NM martensitic stainless steel has been obtained ${ }^{29-31}$.

It is worth to emphasize that, different from nitriding, too little works have been presented in the specialized literature aiming to study the low-temperature plasma nitrocarburizing and carburizing treatment effects on surface properties and characteristics of martensitic stainless steels. In earlier work, a low-temperature plasma nitriding, nitrocarburizing, and carburizing comparative study performed for a single experimental condition $\left(450^{\circ} \mathrm{C}\right.$, and $20 \mathrm{~h}$ treatment temperature, and time, respectively) in AISI 410 martensitic stainless steel substrates was presented $\mathrm{in}^{6}$. In the referred studied condition, it was stated that plasma carburizing did not produce significant hardening effect of the treated surface ${ }^{6}$. On the other hand, the authors of the present work have recently conducted efforts aiming to study the low-temperature carburizing treatment of AISI 420 martensitic stainless steel substrates ${ }^{15,27,28}$, concluding that an adequate choice of carburizing treatment parameters can lead to different results. It is to be noted that both the 410 and 420 steel grades present dissimilar chemical compositions. In accordance with UNS standard, as shown in $^{29}, 410$ steel presents 0.15 wt. $\% \mathrm{C}$, and $11.5-13.5$ wt. $\% \mathrm{Cr}$, and the 420 steel is supposed to have $0.15 \mathrm{wt} . \% \mathrm{C}$ minimum, and 12.0-14.0 wt.\% $\mathrm{Cr}$, on average.

Based on the above-mentioned perspectives, this work brings new arguments on the present subject, aiming to put in evidence the main metallurgical differences of the layers obtained by different low-temperature thermochemical treatments (carburizing, nitriding, and nitrocarburizing) based on the layer growth kinetics, microstructure, phase, and hardness characterization results.

\section{Experimental Procedure}

Cylindrical samples of $10 \mathrm{~mm}$ in height and $9.5 \mathrm{~mm}$ in diameter were cut from AISI 420 steel commercial bar. Samples were oil quenched from $1050^{\circ} \mathrm{C}$ after $0.5 \mathrm{~h}$ austenitizing time (according to $^{30}$ ). The heating rate used was $8.75^{\circ} \mathrm{C} / \mathrm{min}$, and a cooling rate of approximately $105^{\circ} \mathrm{C} / \mathrm{min}$. The hardness of the as-quenched samples was $510 \pm 10 \mathrm{HV}_{0.3}$. A description of heat treatment results (quenching and tempering) of AISI 420 steel, including micrographs, XRD data and hardness values is made in Scheuer ${ }^{31}$. After heat treatment, samples were ground using $\mathrm{SiC}$ sandpaper ranging from 100 to 1200 grade and polished using $1 \mu \mathrm{m} \mathrm{Al}_{2} \mathrm{O}_{3}$ abrasive suspension (following the procedure described by ${ }^{32}$ ). Finally, samples were alcohol cleaned in ultrasonic bath and then introduced into the discharge chamber.

The plasma treatment procedure was divided in two steps:

i) aiming to remove the native oxide layer from sample surface, the specimens were sputter-cleaned by means of a $700 \mathrm{~V}$ peak voltage DC glow discharge, in a gas mixture of $80 \% \mathrm{H}_{2}+20 \% \mathrm{Ar}$, $400 \mathrm{~Pa}$ pressure, at $300^{\circ} \mathrm{C}$, during $0.5 \mathrm{~h}$; and, after cleanness; and,

ii) the specimens were plasma treated in gas mixtures of $99.5 \%\left(80 \% \mathrm{H}_{2}+20 \% \mathrm{Ar}\right)+0.5 \% \mathrm{CH}_{4}$ (carburizing), $71 \% \mathrm{~N}_{2}+18 \% \mathrm{H}_{2}+10 \% \mathrm{Ar}+$ $1 \% \mathrm{CH}_{4}$ (nitrocarburizing), and $70 \% \mathrm{~N}_{2}+20 \% \mathrm{H}_{2}$ $+10 \% \mathrm{Ar}$ (nitriding), in volume, for temperatures of 350,400 and $450^{\circ} \mathrm{C}$, and a single treatment time of $8 \mathrm{~h}$. The total gas flow rate and pressure were kept unaltered for $1.66 \times 10^{-6} \mathrm{Nm}^{3} \mathrm{~s}^{-1}$ and $400 \mathrm{~Pa}$, respectively.

The plasma apparatus is constituted of a $4.16 \mathrm{kHz}$ square-wave pulsed DC power supply, and a stainless steel cylindrical vacuum chamber of $350 \mathrm{~mm}$ in diameter and $380 \mathrm{~mm}$ high, attached to steel plates sealed with silicone o-rings at both the ends (a scheme of the equipment can be found in ${ }^{15}$ ). The system was pumped down to a residual pressure on the order of $3 \mathrm{~Pa}$ using a double stage mechanical vacuum pump. The gas mixture and flow rate of $\mathrm{H}_{2}, \mathrm{~N}_{2}$, Ar and $\mathrm{CH}_{4}$ were adjusted by four mass flow controllers, three of $8.33 \times 10^{-6} \mathrm{Nm}^{3} \mathrm{~s}^{-1}$, and one of $8.33 \times 10^{-8} \mathrm{Nm}^{3} \mathrm{~s}^{-1}$, respectively.

Samples acted as cathode of the discharge, which was negatively biased at $700 \mathrm{~V}$. The samples heating was a result of ions and fast neutrals species bombardment. The mean power transferred to the plasma, and consequently the treatment temperature, was adjusted by varying the switched-on time $\left(\mathrm{t}_{\mathrm{ON}}\right)$ of the pulsed voltage. The temperature was measured by means of a chromelalumel thermocouple (Ktype of $1.5 \mathrm{~mm}$ diameter) inserted $8 \mathrm{~mm}$ depth into the sample holder. The pressure in the vacuum chamber was measured by a capacitive manometer of $1.33 \times 10^{4} \mathrm{~Pa}$ in full-scale operation and adjusted by a manual valve. 
For microstructure analysis purpose, samples were prepared by conventional metallographic procedure. After polishing, the cross-sectioned samples were etched using Marble's reagent $\left(4 \mathrm{~g}_{\text {of }} \mathrm{Cu}_{4} \mathrm{SO}_{4}+20 \mathrm{ml}\right.$ of $\mathrm{HCl}+20 \mathrm{ml}$ of $\left.\mathrm{H}_{2} \mathrm{O}\right)$. Samples were examined using an Optical Microscope (Olympus BX51M). The outer layer thickness determination was taken from OM images, being the image acquisition performed at different points along the layer, aiming to reduce the effect of the metallographic etching quality on the readings accuracy. The identification of the phases present in the treated layers was carried out by X-ray diffractometry (XRD), using a Shimadzu XDR 7000 X-ray diffractometer in the Bragg-Brentano configuration with a $\mathrm{Cu} K \alpha$ Xray tube $(\lambda=0.17889 \mathrm{~nm})$ operated at $40 \mathrm{kV}$ and $20 \mathrm{~mA}$. The diffraction lines were taken with $2 \theta$ in the range of $30-60^{\circ}$ with steps of $0.016^{\circ}$ per second. Microhardness profiles were performed by using a Shimadzu Micro Hardness Tester HMV2T, applying a load of $10 \mathrm{gf}$ and a peak-load contact of $15 \mathrm{~s}$. The points indicated in each profile were obtained from a mean of five measurements. The diffusion layer depth was determined via microhardness profiles, considering that it occurs up to the depth for which the hardness becomes constant (agreeing with the hardness of the substrate bulk). It is to be noted that the bulk hardness varies according to the treatment temperature, since the tempering of the samples was performed simultaneously to the thermochemical treatment. Surface hardness measurements were performed employing the same equipment, applying load of $300 \mathrm{gf}$ and peak-load contact of $15 \mathrm{~s}$. In this case, the indicated surface hardness values are also a mean of five measurements (standard deviation of the obtained average hardness values are also indicated by using error bars for each obtained result).

\section{Results and Discussion}

Figure 1 shows cross-section micrography of samples carburized, nitrocarburized and nitrided at 350, 400 and $450{ }^{\circ} \mathrm{C}$. The presence of a continuous layer on the treated surface is observed for all studied conditions. This surface layer presenting differentiated morphology compared to the

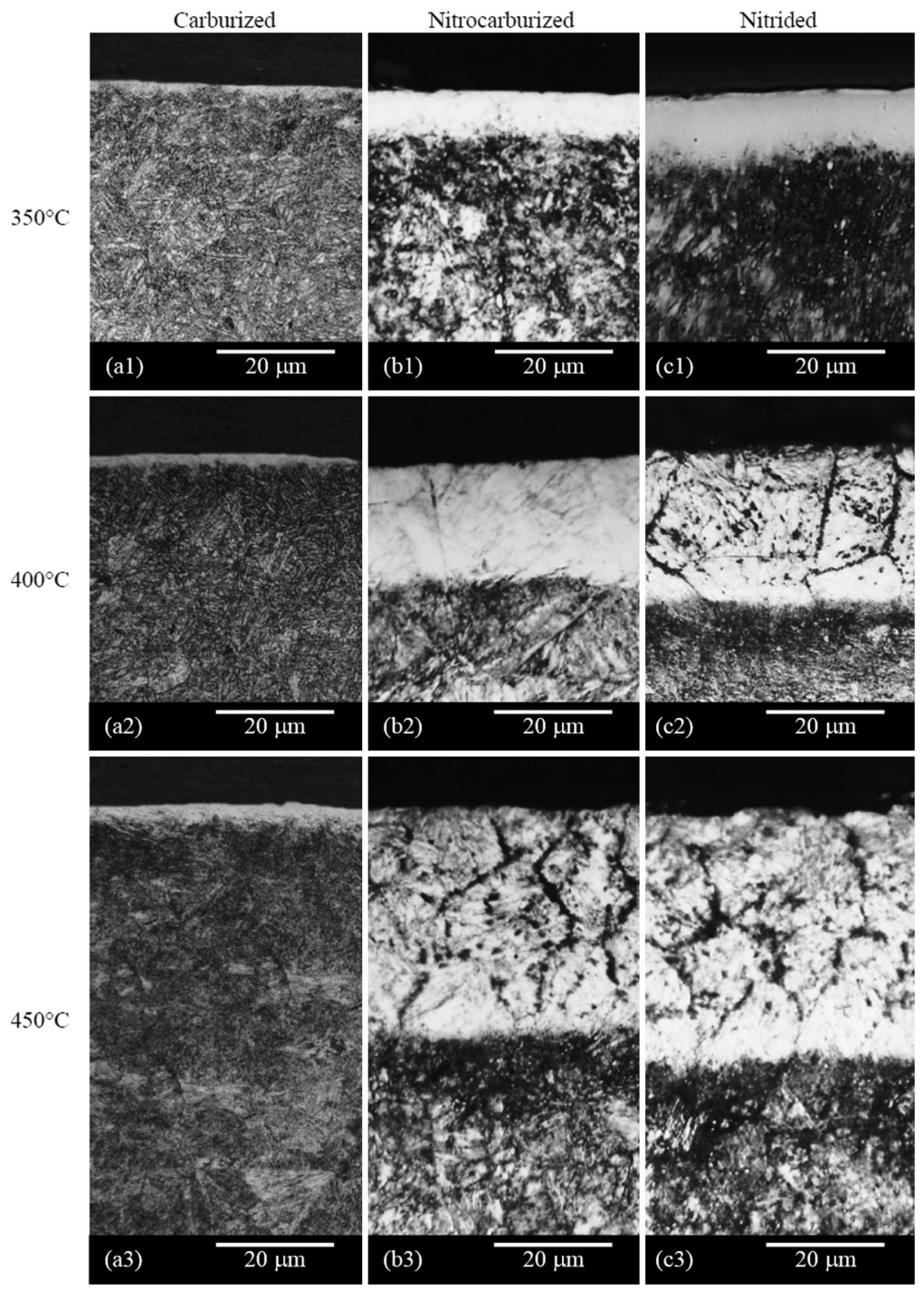

Figure 1. Cross-section micrography of samples carburized, nitrocarburized and nitrided at 350,400 and $450{ }^{\circ} \mathrm{C}$. 
bulk is generated by the nitrogen and/or carbon diffusion, and the consequent formation of nitrogen $\left(\alpha^{\prime} \mathrm{N}\right)$, carbon $\left(\alpha^{\prime} \mathrm{C}\right)$, and/or nitrogen/carbon ( $\left.\alpha^{\prime} \mathrm{NC}\right)$ expanded martensite phase. The layer thickness is directly proportional to the treatment temperature. The nitrided layer is thicker than both the nitrocarburized and carburized one, in agreement with the data presented in Table 1, which shown the thickness of the outer layers obtained by optical microscopy for the studied plasma treatment conditions. It can be also observed the occurrence of a dark-aspect phase present in the layers nitrided and nitrocarburized at 400 and $450{ }^{\circ} \mathrm{C}$, indicating formation of $\mathrm{CrN}$ and/or $\mathrm{Cr}_{\mathrm{x}} \mathrm{C}_{\mathrm{y}}$ precipitates, as a consequence of $\alpha^{\prime}$ and $\alpha^{\prime}{ }_{\mathrm{NC}}$ phase decomposition (precipitation of a second phase in treated layer is usually an indicative of sensitization $^{16}$, and this assertion is supported by the XRD results presented in Figure 2). As already extensively discussed in the literature, the $\mathrm{CrN}$ and $\mathrm{Cr}_{\mathrm{x}} \mathrm{C}_{\mathrm{y}}$ phase formation causes a decrease on material corrosion resistance. However, the dark zone occurrence was not verified for samples nitriding and nitrocarburizing at $350{ }^{\circ} \mathrm{C}$, which show treated surfaces presenting white-aspect single-phase-layers. This result was expected, since $\mathrm{CrN}$ and $\mathrm{Cr}_{\mathrm{x}} \mathrm{C}_{\mathrm{y}}$ precipitation takes place at higher temperatures. For carburized samples, the metallographic analysis data do not exhibit indicative of the sensitization occurrence. It is an indirect evidence that the outer layer generated by carburizing treatment present higher corrosion resistance compared to the material bulk and to the sensitized surface generated by the high temperature nitriding and nitrocarburizing treatments. For samples nitrided and carburided at temperatures of 400 and $450{ }^{\circ} \mathrm{C}$, the microstructure in the diffusion zone appeared to be more attacked compared to that in the substrate (bulk). However, in these cases the diffusion zone depth could not be measured by the metallographic analysis, since there was no clear boundary between the diffusion layer and the substrate.

X-ray diffraction patterns of untreated (as-quenched) and plasma nitrided, carburized and nitrocarburized samples, treated at 350,400 and $450{ }^{\circ} \mathrm{C}$ are shown in Figure 2a-c, respectively. The as-quenched sample presents a typical peak related to the martensite phase $\left(\alpha^{\prime}\right)$, which is in agreement with Xi et al. ${ }^{18-20}$. XRD data revealed peak reflections related to $\mathrm{Fe}_{3} \mathrm{C}$ phase for all studied carburizing treatment conditions. However, the occurrence of $\alpha^{\prime}{ }_{\mathrm{C}}$ phase reflections is only observed for the $450{ }^{\circ} \mathrm{C}$ treatment condition, although the occurrence of this phase has been evident in the micrographs shown in Figure 1 (a1-a3). The reason for the non-occurrence of $\alpha_{\mathrm{C}}$, reflections on XRD data for samples treated for 350 and $400^{\circ} \mathrm{C}$ may be linked to the lower carburized outer layer thickness obtained in these conditions (according values shown in Table 1). In these cases, it is assumed that the carburized layer was too thin to be detected by the used

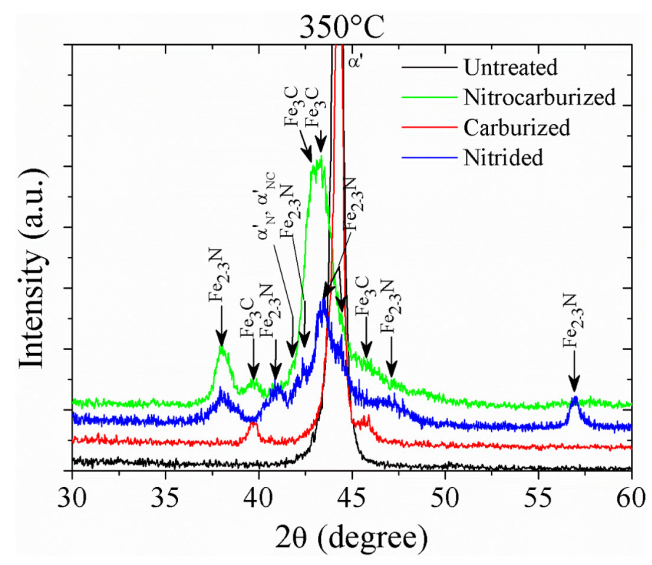

(a)

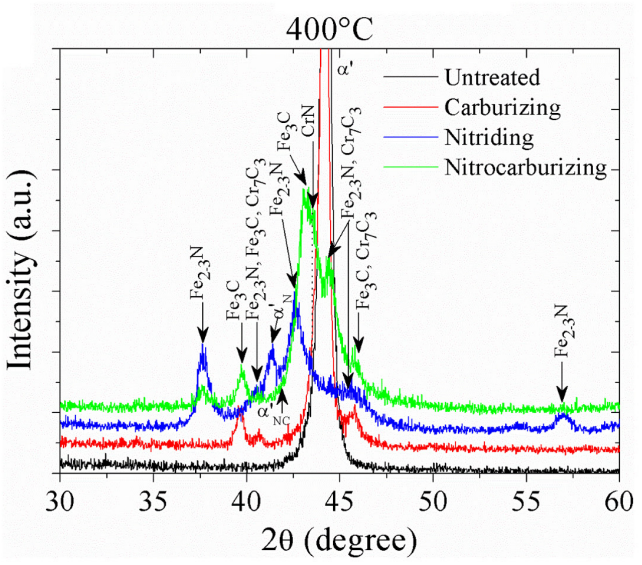

(b)

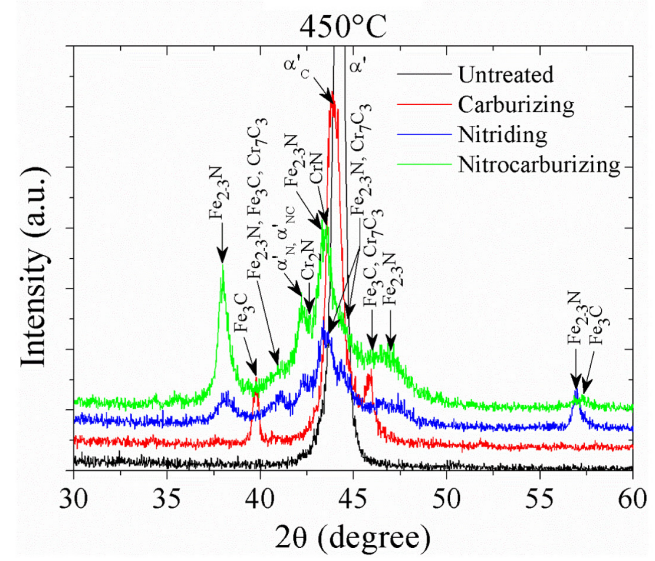

(c)

Figure 2. XRD patterns of the treated samples treated at: (a) 350 ; (b) 400 and (c) $450{ }^{\circ} \mathrm{C}$.

Table 1. Thickness of the outer and diffusion layers obtained for the studied plasma treatment conditions.

\begin{tabular}{cccc}
\hline \multirow{2}{*}{ Treatment temperature $\left({ }^{\circ} \mathbf{C}\right)$} & Outer layer thickness $(\boldsymbol{\mu m})$ \\
\cline { 2 - 3 } & Carburizing & Nitrocarburizing & Nitriding \\
\hline 350 & $1.5 \pm 0.2$ & $4.6 \pm 0.8$ & $9.8 \pm 1.1$ \\
400 & $1.8 \pm 0.2$ & $17.5 \pm 0.4$ & $21.2 \pm 0.8$ \\
450 & $2.2 \pm 0.2$ & $45.8 \pm 0.9$ & $60.7 \pm 0.7$ \\
\hline
\end{tabular}


$\theta$-2 $\theta$ XRD configuration. Moreover, no peak reflections related to chromium carbide was verified for carburized samples. Despite of it, sensitization occurrence cannot be completely ruled out, since the characterization techniques employed in present work are not accurate enough to identify the occurrence of secondary phases precipitated in nano-scale, thus additional efforts are necessary to clearly elucidate this opened-point in this case. For nitrocarburized samples treated at $350{ }^{\circ} \mathrm{C}$ (Figure $2 \mathrm{a}$ ), the phases are mainly $\alpha{ }_{\mathrm{NC}}, \mathrm{Fe}_{3} \mathrm{C}$, and $\varepsilon-\mathrm{Fe}_{2-3} \mathrm{~N}$ (see Figure 1 (b1)), and treated at higher temperatures of 400 , and $450{ }^{\circ} \mathrm{C}$ (Figure $2 \mathrm{~b}, \mathrm{c}$ ) results indicate the presence of nitrogen/carbon-expanded martensite phase $\left(\alpha_{\mathrm{NC}}\right)$, iron carbide, and iron nitride phases $\left(\mathrm{Fe}_{3} \mathrm{C}\right.$, and $\left.\varepsilon-\mathrm{Fe}_{2-3} \mathrm{~N}\right)$, beyond $\mathrm{CrN}$, and $\mathrm{Cr}_{7} \mathrm{C}_{3}$ phases, confirming the sensitization shown in Figure 1 (b2, and b3, respectively). Finally, for $350^{\circ} \mathrm{C}$ low-temperature plasma nitrided samples, the phases are mainly $\alpha^{\prime}$ and $\varepsilon-\mathrm{Fe}_{2-3} \mathrm{~N}$ (Figure 2a). In this case, no precipitation of chromium nitride phases is present, as shown in Figure 1 (c1) micrograph. For higher nitriding temperatures, at 400 and $450{ }^{\circ} \mathrm{C}$ (Figure $2 \mathrm{~b}, \mathrm{c}$ ), XRD pattern results suggest $\mathrm{CrN}$ precipitation, and thus the occurrence of sensitization, as indicated in Figure 1 (c2, and c3, respectively). It is worth to emphasize that the peaks position of expanded martensite phases are continuously changed according to the treatment temperature, independently of the thermochemical process. In this case, it is supposed that the referred positions are changed to smaller $2 \theta$ angles by increasing the used temperature from 350 to $400{ }^{\circ} \mathrm{C}$, but they tend to return to higher $2 \theta$ angles by increasing the used temperature from 400 to $450{ }^{\circ} \mathrm{C}$, this change in position being due to the increment or decrease of $\mathrm{N} / \mathrm{C}$ concentration in the related phases.

It is important to clarify that, despite our results on the carburized layers have indicated no chromium carbide phase precipitation, its occurrence cannot be totally disregarded. This is due to the fact that, as previously observed, the characterization techniques and the related parameters used here were not able to identify the occurrence of nano-precipitates of secondary phases in nano-scale. Notwithstanding, it is worth to be mentioned that the incidence of nanometric phases in layers obtained by thermochemical treatments have been evidenced by authors of different works ${ }^{33,34}$, only by employing High-Resolution Transmission Electron Microscopy (HR-TEM) characterization.

Analyzing the data of the outer layer thickness (Table 1) against time, an Arrhenius-type plot was constructed (Figure 3). By linearization of Arrhenius plot data the activation energy for diffusion of nitrogen/carbon during the plasma assisted process was obtained. The estimated activation energy for treated layer growth presents distinct values for the different treatments, being higher for the nitrocarburizing treatment, followed by the nitriding and carburizing, on this order. It was found that the nitrocarburizing treatment has the highest activation energy $\left(173 \mathrm{kJmol}^{-1}\right)$, followed by the nitriding treatment $\left(136 \mathrm{kJmol}^{-1}\right)$, being that the carburizing process presented the lowest value $\left(29 \mathrm{kJmol}^{-1}\right)$. According to Pinedo \& Monteiro ${ }^{35}$, activation energy of $125.13 \mathrm{kJmol}^{-1}$ was obtained for AISI 420 steel samples nitrided at 480 to $560{ }^{\circ} \mathrm{C}$ and $4 \mathrm{~h}$ treatment time, in a dc-plasma apparatus. Kim et al. ${ }^{14}$ showed that the activation energy for low-temperature RF-plasma nitriding of AISI 420 steel is $33.4 \mathrm{kJmol}^{-1}$, for treatment condition of 350 to $500{ }^{\circ} \mathrm{C}$ and $4 \mathrm{~h}$. Activation energy of $60.0,92.0$ and $164.0 \mathrm{kJmol}^{-1}$ was verified for low-temperature dc-plasma nitriding (at 300 to $500{ }^{\circ} \mathrm{C}$, and $4 \mathrm{~h}$ treatment time) of as-quenched, tempered and annealed AISI 420 steel samples, respectively ${ }^{36}$. On the other hand, and activation energy of $84 \mathrm{kJmol}^{-1}$ was obtained for lowtemperature dc-plasma nitrocarburizing (at 300 to $450{ }^{\circ} \mathrm{C}$, and $4 \mathrm{~h}$ treatment time) of AISI 420 steel samples ${ }^{37}$. It is important to bear in mind that for the treatments to which no nitride/carbide precipitation occurs, the volume diffusion of nitrogen/carbon through the modified layer is the main phenomenon, affecting significantly the process kinetics. Contrarily, the occurrence of nitride/carbide precipitation (which generally occurs for long-term and high-temperature plasma treatments) affects the nitrided/nitrocarburized layer growth, affecting directly the process kinetics, decreasing the diffusion coefficient and increasing the activation energy ${ }^{25}$. This is the cause of the higher activation energy for nitriding and nitrocarburizing compared to carburizing processes.

The evolution of the surface hardness of low-temperature plasma treated AISI 420 martensitic stainless steel for the studied conditions is presented in Figure 4. Measurements were performed on the top (surface exposed to the plasma) and bottom of the samples (surface non-exposed to the

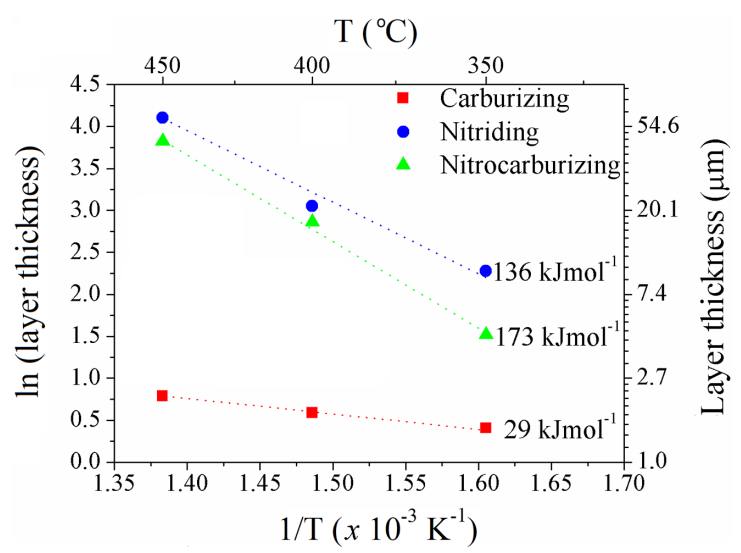

Figure 3. Arrhenius plot of the layer thickness for the low-temperature plasma treated surfaces (for treatments carried out at $8 \mathrm{~h}$ ).

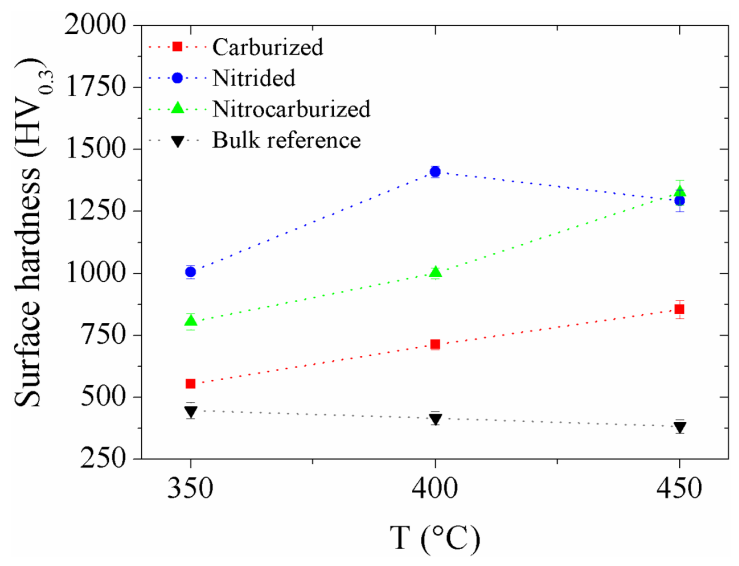

Figure 4. Surface hardness of the treated samples as a function of the treatment temperature (for treatments carried out at $8 \mathrm{~h}$ ). 
plasma, being also representative of the substrate bulk). Results indicate that all the studied treatments promote an increase of the surface hardness when compared with the bulk hardness. The nitriding and nitrocarburizing treatments lead to the highest surface hardness, but the slightest hardness increase was verified to carburized samples. Surface hardness on average (+ standard deviation) of $555(+15), 1005(+25)$, and $805(+35) \mathrm{HV}_{0.3}$ for samples carburized, nitrided, and nitrocarburized at $350{ }^{\circ} \mathrm{C}$, of $710(+20), 1410(+25)$, and $1000(+20) \mathrm{HV}_{0.3}$ at $400{ }^{\circ} \mathrm{C}$, and of $855(+35), 1295(+45)$, and $1325(+50) \mathrm{HV}_{0.3}$ at $450{ }^{\circ} \mathrm{C}$, respectively. The distinct results verified for the different treatments are related to the different phases and thickness obtained in the treated layers. In general, the hardness increase is due to the addition of nitrogen/carbon into solid solution in martensite lattice, allied to the formation of $\varepsilon-\mathrm{Fe}_{2-3} \mathrm{~N}$ and $\mathrm{Fe}_{3} \mathrm{C}$ phases. As the measured hardness valued is affected by the layer thickness growth, thicker the formed layer higher is the measured hardness, which is in agreement with Figures 2 and 3 results. For carburized and nitrocarburized samples surface hardness increases steadily by increasing the treatment temperature, but this same behavior was not observed for nitrided samples. It is to be observed that precipitation of second phases in carburized layers has not been observed in the studied treatment temperatures, as previously presented $i^{15}$, which shows that it occurs for samples carburized at temperatures higher than $450{ }^{\circ} \mathrm{C}$, in present case. On the other hand, precipitation in treated layer seems to be retarded in nitrocarburized samples, for the results confronted with those obtained for nitrided ones. It is evidenced that nitrided sample shows strong precipitation at $400{ }^{\circ} \mathrm{C}$, by comparing Figure 1 (b2, c2) results obtained for nitrocarburized, and nitrided samples, respectively. In addition, the hardness decrease evidenced at $450{ }^{\circ} \mathrm{C}$ for the nitriding treatment would be directly related to the strong nitride precipitation. This precipitation would reduce the nitrogen content in solid solution and, consequently, the nitrogen-expanded martensite hardness, as a result of the structure relaxation. Finally, a hardness decrease of the sample bulk was verified for all the treated samples, which is a result of the martensite tempering effect. Confronting the sample top and bottom hardness results, it can be noticed that the plasma assisted treatments strengthening effect overcomes the tempering softening one (bulk hardness of $445(+30), 415(+25)$ and $385(+25) \mathrm{HV}_{0.3}$ were observed for samples treated at 350 , 400 and $450{ }^{\circ} \mathrm{C}$, respectively). This evidences that the low-temperature plasma assisted treatments studied here can be successfully applied to improve the surface strength of AISI 420 steel.

Microhardness profiles of samples treated at 350, 400, and $450{ }^{\circ} \mathrm{C}$ are shown in Figure $5 \mathrm{a}-\mathrm{c}$, respectively. Figure $5 \mathrm{a}$ indicates hardness values of $590(+20), 990(+15)$, and $575(+20) \mathrm{HV}_{0.01}$, to a depth on the order of $5 \mu \mathrm{m}$, and hardening depth on the order of 20,15 , and $15 \mu \mathrm{m}$, for samples carburized, nitrided, and nitrocarburized at $350{ }^{\circ} \mathrm{C}$, respectively. Figure $5 \mathrm{~b}$ indicates hardness values of 740 $(+40), 1310(+25)$, and $955(+20) \mathrm{HV}_{0.01}$, to a depth of $5 \mu \mathrm{m}$, and hardening depth of about 40,25 , and $25 \mu \mathrm{m}$, for samples carburized, nitrided, and nitrocarburized at $400{ }^{\circ} \mathrm{C}$, respectively. Finally, Figure 5c shows hardness values of

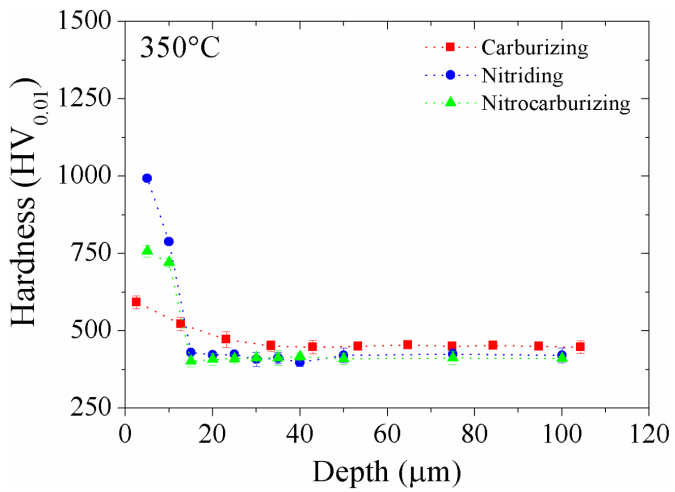

(a)

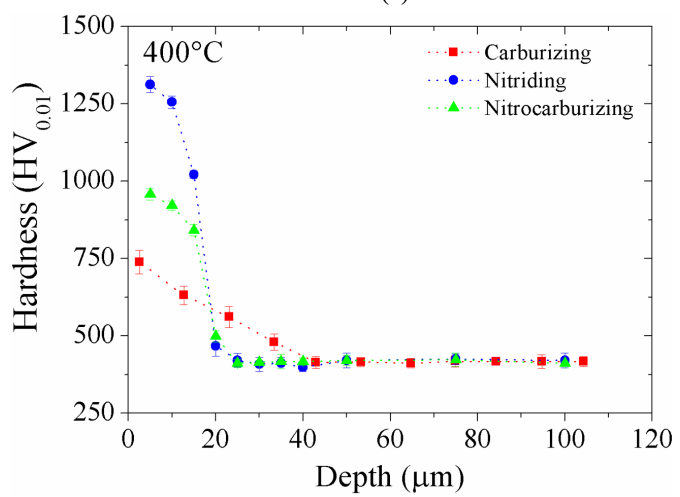

(b)

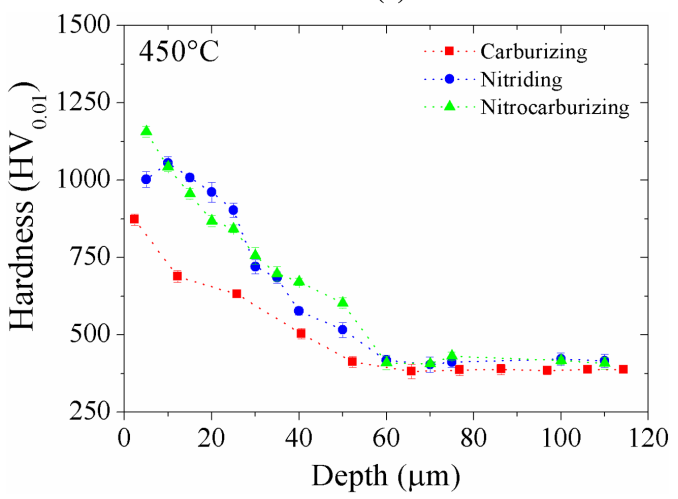

(c)

Figure 5. Microhardness profiles of samples treated by carburizing, nitriding and nitrocarburizing during $8 \mathrm{~h}$ at: (a) 350; (b) 400 and (c) $450^{\circ} \mathrm{C}$.

$870(+20), 1000(+25)$, and $1155(+15) \mathrm{HV}_{0.01}$, to a depth of $5 \mu \mathrm{m}$, and hardening depth on the order of $60 \mu \mathrm{m}$ for all the studied conditions, for samples carburized, nitrided, and nitrocarburized at $450{ }^{\circ} \mathrm{C}$, respectively. For the case of nitriding, carburizing and nitrocarburizing treatments, the hardness of treated surface is a function of its nitrogen/carbon content, so, the hardness decrease could be important evidence that nitrogen/carbon diffuses as interstitial atom into the steel matrix, being an indication of the existence of a nitrogen/carbon concentration gradient below surface. For the highest treatment temperature, the carbide/nitride precipitate formation consumes significant amount of carbon/ 
nitrogen, thus reducing the concentration gradient of these elements in solid solution, slowing down its diffusion depths in the martensitic lattice. It is also worth to be pointed out that the nitriding, carburized and nitrocarburized layers are constituted of an outer and diffusion layers, being the diffusion layer evidenced by the microhardness profiles only. From Figure 5a-c, the bulk hardness was around $440(+20), 420$ $(+40)$, and $395(+15) \mathrm{HV}_{0.3}$, for all the samples treated at 350,400 and $450^{\circ} \mathrm{C}$, respectively. This result is in agreement with that presented in Figure 4, for untreated surfaces (bulk), confirming the different tempering effects verified for each treatment temperature.

\section{Conclusion}

A comparison study comprising low-temperature plasma assisted nitriding, carburizing, and nitrocarburizing treatments in AISI 420 steel substrates was performed using optical microscopy, $\theta-2 \theta$ XRD technique, and mechanical characterization. The main conclusions can be listed as follows:

- Through the characterization techniques employed in the present work, the occurrence of chromium carbide precipitation was not verified for samples carburized at 350,400 and $450{ }^{\circ} \mathrm{C}$;

- Nitriding and nitrocarburizing carried out at 400 and $450{ }^{\circ} \mathrm{C}$ lead the obtained treated layers to present chromium-nitride/-carbide precipitation, respectively;

\section{References}

1. Czerwinski F. Thermochemical treatment of metals. In: Czerwinski F, editor. Heat treatment: conventional and novel applications. Rijeka: InTech; 2012. 73-112. doi: http://dx.doi. org/10.5772/51566.

2. Edenhofer B, Gräfen W and Müller-Ziller J. Plasma-carburising: a surface heat treatment process for the new century. Surface and Coatings Technology. 2001; 142:225-234. http://dx.doi. org/10.1016/S0257-8972(01)01136-7.

3. Bell T, Sun Y and Suhadi A. Environmental and technical aspects of plasma nitrocarburising. Vacuum. 2000; 59(1):14-23. http:// dx.doi.org/10.1016/S0042-207X(00)00250-5.

4. Bell T and Dearnley PA. Environmental issues in surface engineering and related industrial sectors. Surface Engineering. 1994; 10(2):123-128. http://dx.doi.org/10.1179/sur.1994.10.2.123.

5. Staines AM and Bell T. Technological importance of plasmainduced nitrided and carburized layers on steel. Thin Solid Films. 1981; 86(201):201-212. http://dx.doi.org/10.1016/00406090(81)90289-3.

6. Li CX and Bell T. A comparative study of low temperature plasma nitriding, carburising and nitrocarburising of AISI 410 martensitic stainless steel. Materials Science and Technology. 2007; 23(3):355-361. http://dx.doi.org/10.1179/174328407X161204.

7. Zhang ZL and Bell T. Structure and corrosion resistance of plasma nitride stainless steel. Surface Engineering. 1985; 1(2):131-136. http://dx.doi.org/10.1179/sur.1985.1.2.131.

8. Sun Y, Bell T and Wood G. Wear behaviour of plasma-nitrided martensitic stainless steel. Wear. 1994; 178(1-2):131-138. http:// dx.doi.org/10.1016/0043-1648(94)90138-4.
- The increase of the treatment temperature causes an increase on the treated layer thickness and hardness, as well as on hardening depth of the treated samples.

- The high hardness measured for the treated layers is due to the $\mathrm{C}$-/ $\mathrm{N}$-expanded martensite phase formation and eventual occurrence of iron-carbide/-nitride formation.

- The kinetics of the layer growth is a function of the diffusing component, namely $\mathrm{C}, \mathrm{N}$, or $\mathrm{C}+\mathrm{N}$. The estimated activation energy was 29, 136 and $173 \mathrm{kJmol}^{-1}$ for plasma carburized, nitrided and nitrocarburized samples, respectively.

\section{Acknowledgements}

This work was supported by CNPq, Fundação Araucária of the Paraná State, CNPq-Universal Grant N. 482380/2012-8, and MCTI/CNPq/CT-Aquaviário Grant N. 456347/2013-5, CAPES-COFECUB and Programa Interdisciplinar de Petróleo e Gás Natural da UFPR (PRH-24). The authors also wish to express their thanks to the Laboratory of X-ray Optics and Instrumentation - LORXI, from Universidade Federal do Paraná (UFPR) for the use of the X-ray diffraction equipment.

9. Li CX and Bell T. Corrosion properties of plasma nitrided AISI 410 martensitic stainless steel in $3.5 \% \mathrm{NaCl}$ and $1 \% \mathrm{HCl}$ aqueous solutions. Corrosion Science. 2006; 48(8):2036-2049. http://dx.doi.org/10.1016/j.corsci.2005.08.011.

10. Sun Y and Bell T. Sliding wear characteristics of low temperature plasma nitrided 316 austenitic stainless steel. Wear. 1998; 218(1):34-42. http://dx.doi.org/10.1016/S0043-1648(98)00199-9.

11. Menthe E, Rie KT, Schultze JW and Simson S. Structure and properties of plasma-nitrided stainless steel. Surface and Coatings Technology. 1995; 74-75:412-416. http://dx.doi. org/10.1016/0257-8972(95)08246-8.

12. Menthe E, Bulak A, Olfe J, Zimmermann A and Rie KT. Improvement of the mechanical properties of austenitic stainless steel after plasma nitriding. Surface and Coatings Technology. 2000; 133-134:259-263. http://dx.doi.org/10.1016/S02578972(00)00930-0.

13. Borgioli F, Fossati A, Galvanetto E and Bacci T. Glow-discharge nitriding of AISI 316L austenitic stainless steel: influence of treatment temperature. Surface and Coatings Technology. 2005; 200(7):2474-2480. http://dx.doi.org/10.1016/j.surfcoat.2004.07.110.

14. Kim SK, Yoo JS, Priest JM and Fewell MP. Characteristics of martensitic stainless steel nitrided in a low-pressure RF plasma. Surface and Coatings Technology. 2003; 163-164:380-385. http://dx.doi.org/10.1016/S0257-8972(02)00631-X.

15. Scheuer CJ, Cardoso RP, Mafra M and Brunatto SF. AISI 420 martensitic stainless steel low-temperature plasma assisted carburizing kinetics. Surface and Coatings Technology. 2013; 24:30-37. http://dx.doi.org/10.1016/j.surfcoat.2012.10.060.

16. Corengia P, Ybarra G, Moina C, Cabo A and Broitman E. Microstructure and corrosion behaviour of DC-pulsed plasma nitride AISI 410 martensitic stainless steel. Surface and Coatings 
Technology. 2004; 187(1):63-69. http://dx.doi.org/10.1016/j. surfcoat.2004.01.031.

17. Corengia P, Walther F, Ybarra G, Sommadossi S, Corbari R and Broitman E. Friction and rolling: sliding wear of DC-pulsed plasma nitrided AISI 410 martensitic stainless steel. Wear. 2006; 260(4-5):479-485. http://dx.doi.org/10.1016/j.wear.2005.03.008.

18. Xi CX, Liu DX and Han D. Improvement of mechanical properties of Martensitic stainless steel by plasma Nitriding at low temperature. Acta Metallurgica Sinica. English Letters. 2008; 21(1):21-29. http://dx.doi.org/10.1016/S1006-7191(08)60015-0.

19. Xi CX, Liu DX and Han D. Improvement of corrosion and wear resistances of AISI 420 martensitic stainless steel using plasma nitriding at low temperature. Surface and Coatings Technology. 2008; 202(12):2577-2583. http://dx.doi.org/10.1016/j. surfcoat.2007.09.036.

20. Xi CX, Liu DX and Han D. Improvement of erosion and erosion-corrosion resistance of AISI 420 stainless steel by low temperature plasma nitriding. Applied Surface Science. 2008; 254(18):5953-5958. http://dx.doi.org/10.1016/j.apsusc.2008.03.189.

21. Espitia LA, Varela L, Pinedo CE and Tschiptschin AP. Cavitation erosion resistance of low temperature plasma nitrided martensitic stainless steel. Wear. 2013; 301(1-2):449-456. http://dx.doi. org/10.1016/j.wear.2012.12.029.

22. Fernandes FAP, Totten GE, Gallego J and Casteletti LC. Plasma nitriding and nitrocarburising of a supermartensitic stainless steel. International Heat Treatment and Surface Engineering. 2012; 6(1):24-27. http://dx.doi.org/10.1179/1749514811Z.0000000008.

23. Liu RL and Yan MF. Improvement of wear and corrosion resistances of 17-4PH stainless steel by plasma nitrocarburizing. Materials \& Design. 2010; 31(5):2355-2359. http://dx.doi. org/10.1016/j.matdes.2009.11.069.

24. Yan MF and Liu RL. Influence of process time on microstructure and properties of 17-4PH steel plasma nitrocarburized with rare earths addition at low temperature. Applied Surface Science. 2010; 256(20):6065-6071. http://dx.doi.org/10.1016/j. apsusc.2010.03.121.

25. Yan MF, Liu RL and Wu DL. Improving the mechanical properties of 17-4PH stainless steel by low temperature plasma surface treatment. Materials \& Design. 2010; 31(4):2270-2273. http:// dx.doi.org/10.1016/j.matdes.2009.10.005.

26. Liu RL, Yan MF, Wu YQ and Zhao CZ. Microstructure and properties of 17-4PH steel plasma nitrocarburized with a carrier gas containing rare earth elements. Materials Characterization. 2010; 61(1):19-24. http://dx.doi.org/10.1016/j.matchar.2009.09.017.
27. Scheuer CJ, Cardoso RP, Zanetti FI, Amaral T and Brunatto SF. Low-temperature plasma carburizing of AISI 420 martensitic stainless steel: Influence of gas mixture and gas flow rate. Surface and Coatings Technology. 2012; 206(24):5085-5090. http://dx.doi.org/10.1016/j.surfcoat.2012.06.022.

28. Scheuer CJ, Cardoso RP, Pereira R, Mafra M and Brunatto SF. Low temperature plasma carburizing of martensitic stainless steel. Materials Science and Engineering A. 2012; 539:369-372. http://dx.doi.org/10.1016/j.msea.2012.01.085.

29. Lippold JC and Kotecki DJ. Welding metallurgy and weldability of stainless steels. Hoboken: John Wiley \& Sons; 2005. p. 357.

30. Orlich J, Rose A and Wever F. Atlas Zur Wärmebehandlung Der Stähle. Dusseldorf: Verlag Stahleisen GmbH; 1954. v. 1.

31. Scheuer CJ. Cementação a baixa temperatura do aço inoxidável martensítico AISI 420 assistida por plasma. [Thesis]. Curitiba: Federal University of Paraná; 2011. (in Portuguese). Available from: $<$ http://www.pgmec.ufpr.br/dissertacoes/dissertacao_121_ cristiano_jose_scheuer.pdf $>$. Access in: 09 Mar. 2014.

32. Vander Voort GF and James HM. Wrought stainless steels. In: ASM Handbook: Metallography and Microstructures. Ohio: ASM International; 1992. v. 9. p. 279-296.

33. Cao Y, Ernst F and Michal G. Colossal carbon supersaturation in austenitic stainless steels carburized at low temperature. Acta Materialia. 2003; 51(14):4171-4181. http://dx.doi.org/10.1016/ S1359-6454(03)00235-0.

34. Zagonel LF, Bettini J, Basso RLO, Paredez P, Pinto H, Lepienski $\mathrm{CM}$, et al. Nanosized precipitates in $\mathrm{H} 13$ tool steel low temperature plasma nitriding. Surface and Coatings Technology. 2012; 207:72-78. http://dx.doi.org/10.1016/j.surfcoat.2012.05.081.

35. Pinedo CE and Monteiro WA. On the kinetics of plasma nitriding a martensitic stainless steel type AISI 420. Surface and Coatings Technology. 2004; 179(2-3):119-123. http://dx.doi.org/10.1016/ S0257-8972(03)00853-3.

36. Cardoso RP, Scheuer CJ and Brunatto SF. Low-temperature nitriding kinetics of stainless steel: effect of prior heat treatment. In: Encyclopedia of iron, steel, and their alloys. New York: Taylor \& Francis. In press.

37. Anjos AD, Scheuer CJ, Brunatto SF and Cardoso RP. Lowtemperature plasma nitrocarburizing of the AISI 420 martensitic stainless steel: microstructure and process kinetics. Surface and Coatings Technology. 2015; 15:51-57. http://dx.doi.org/10.1016/j. surfcoat.2015.03.039. 